\title{
The Values of Achievement at the Gayo Traditional Horse Racing Sports in Bener Meriah
}

\author{
Putra Arima \\ Sports Education Postgraduate Program \\ Medan State University \\ Medan, North Utara \\ Putraarima9@gmail.com
}

\author{
Tarsyad Nugraha/ Agung Sunarno \\ Sports Education Postgraduate Program \\ Medan State University \\ Medan, North Utara \\ cats_unimed@gmail.com /agungs_fikunimed@yahoo.com
}

\begin{abstract}
This study aims to determine the values of achievement that exist in the traditional Gayo horse racing sport. Because during this time the horse race was only considered as people's entertainment, which was initially held at the edge of the lauttawar lake of Takengon to enliven the success of the rice harvest. This research is a descriptive qualitative research conducted in Bener Meriah, Aceh. The samples in this study were the tourism department of Bener Meriah, Horse Owner, and Horse Race Jockey amount of 12 people. The method of data collection is done by observation, interviews, and documentation. Then the data obtained were analyzed by qualitative analysis with non statistical descriptive analysis. The results of the research show that the achievement values contained in the horse racing competition are carried out traditionally. Like a jockey must has a strong mentality and must also has high motivation to help support jockey's achievements to the best result. The main goal is not only the victory gained at the racetrack, but the important thing is to strive to achieve victory well. The struggle to achieve victory in a healthy way, does not justify everything for a victory to achieve goals achievement. To achieve an achievement must apply sports values such as sportsmanship, honesty, and responsibility in carrying out the training process provided.
\end{abstract}

Keywords : Traditional Horse Racing, Achievement Value, Bener Meriah.

\section{INTRODUCTION}

Horse Racing is a horse racing event held in an open field to enliven the success of the rice harvest. At first it was just a fun activity for the village youths in Gayo, especially in Bintang and around settlements around Lake LautTawar. It has become a habit of young people, catching horses that roam with sarong without the knowledge of their owners and spur them on. When spurred, sometimes simultaneously with groups of youth from other villages, who do the same thing. Then there was social interaction, where the jockeys of each village agreed to hold a horse race match between the villages without a prize for the winner only "Gah" or marwah. It was not realized, finally since the early 1930s, this activity turned into an annual tradition involving several villages. The interesting thing from this traditional Pacu Horse tradition is that the jokinya is young with an age range of 10-16 years, the jockey's expertise is obtained naturally, brave without wearing a saddle. These jockeys are only enough to wear T-shirts and shorts that are commonly worn everyday, and without other body armor ( Piet Rusdi : 2011 ). But in its development, horse racing has now become a big event in the Gayo highlands that is fighting over prizes and fervor and selfrespect for the race participants. In this horse race the jockey and horse owner are very ambitious to become champions because that is one of the goals of this horse race, the horse that gets to finish first is the winner. All types of sports activities have a specific purpose even though it is done traditionally. In traditional sports, especially horse racing which has been entrenched in the life of the Gayo people also contains elements of uncertainty, surprise and even there is also an element of luck in gaining victory in competitions held. However, the jockey and the horse that is ridden must have a thorough preparation to be able to achieve the goal of achievement in the horse racing competition held in the highlands of Gayo.

In an effort to achieve better results, there are risk factors, difficulties, and even failures that end in frustration. Even though what we want to achieve is excellence, but that does not mean to justify any means such as pulling clothes, kicking, even injuring other jockeys when the race is in progress. so that horse racing must be humane based on ethical and moral fair play.

Horse racing activity is a place to channel hobbies for horse lovers who compete to achieve achievements. Although at present the achievements in this horse racing activity are still at the regional level, the jockeys riding the horse remain enthusiastic in preparing themselves to achieve maximum achievements. To be able to achieve maximum achievement must have preparation because horse racing is a sport that has a fairly high level of difficulty. In this case the jockey must have strength, balance, concentration, and good coordination, as well as mastering the basic techniques

of youth and skills in controlling horses. To be able to do that all can not be separated from physical training, techniques, tactics, and mental. In accordance with the opinionIrianto (2002 : 65), Physical is the foundation of sporting achievements because techniques, challenges and mentality can be developed properly if they have good 
physical qualities. An athlete will develop his skills from basic techniques to further techniques that will have sufficient skills. The main foundation of athlete selection is the initial physical condition of the prospective athlete, the main physical involved in the training process, with a good physical technique, combination, and mental can be improved according to the training process, physical support does not support the selection of athletes so that athletes cannot display support maximal technique, motivation and mentality therefore special talent guides are needed, because the initial training is the availability of quality athletes seeds. Sardiman A.M (2001:46) also revealed that achievement is a real ability in competition which is the result of interaction between various factors that affect both inside and outside individuals.

\section{METHOD}

This research is a qualitative descriptive study. This research was conducted by focusing on the achievement values in the traditional Gayo horse racing in Bener Meriah. In this study the research subjects were determined by purposive sampling with 15 respondents. Data collection techniques used in this study include observation, interview, and documentation techniques. Analysis of qualitative data with non-statistical analytic descriptive.c onducted through the stages of data collection, data reduction, data presentation and data verification.

\section{DISCUSSION}

Bener Meriah Regency is one of the Regencies located in the Gayo Highlands in Aceh Province which is a division of Central Aceh District, Bener Meriah Regency was established under Law number 41 of 2003, concerning the Establishment of Bener Meriah Regency in the Province of Nanggroe Aceh Darussalam. With the contour of the hilly area and high level, the majority of the population are farmers, with superior commodity coffee and agricultural products.

Bener Meriah Regency is located between 40 33'50 "- 40 54'50" North Latitude and 960 40'75 "- 970 17'50" East Longitude in the median of Aceh Province. The total area of Bener Meriah Regency is $1,919.70 \mathrm{~km} 2$ with the following boundaries:

- West side is bordered by Central Aceh Regency;

- East side is bordered by East Aceh Regency;

- North side is bordered by North Aceh and Bireun Regencies;

- South side is bordered by Central Aceh Regency.

Topographically the area of Bener Meriah Regency is in the Bukit Barisan plains with hilly and slightly overgrown land with a slope of land ranging from 00 - 30 around 2\%, 30 80 around $8.5 \%, 50-400$ around $54.4 \%$ and above 400 around $35.36 \%$. Average height above sea level 100-2500 meters. This condition makes Bener Meriah a very fertile area as an agricultural area.
Bener Meriah Regency consists of 10 sub-districts, 27 mukim with a definitive village of 233 and a hamlet of 551 . Bener Meriah Regency is a tropical region with annual rainfall ranging from 143 - 178 days. The maximum temperature ranges from $80 \mathrm{C}$ - 230C. Maximum relative humidity is $75.8 \%$ and minimum 20\%. (ProfilKesehatanBener Meriah, $2016: 4)$.

The Bener Meriah community has a traditional Gayo horse racing sport event which has been held to date, usually held in January to coincide with the anniversary of Bener Meriah district in the Sengeda field, located at the foot of BurniTelong (Volcano) adjacent to Rembele Airport (Airport). In Bener Meriah, a horse race was held to commemorate the Anniversary of the Regency which was inaugurated by the Minister of the Interior on 7 January 2004.

In this horse race the winners are the jockey and the horse he rides is superior to the other jockey and gets to the finish line first. To be superior to opponents on the runway is not an easy matter. Of course, must have a thorough preparation, ranging from physical, technical, tactic and mental good to achieve the desired performance. As revealed Harsono (1988: 154), if physical condition is good then: (1) there will be an increase in the ability of the circulatory system and the work of the heart. (2) there will be an increase in strength, flexibility, stamina, speed and other physical condition components. (3) there will be a better motion economy at practice. (4) there will be a faster recovery in the organs of the body after exercise. (5) there will be a rapid response from the body's organism at any time if such a response is needed. So a jockey must have a physical condition that needs to be prepared carefully, especially has a strong grip to hold the horse's bridle and hold the horse coward so as not to fall when the horse is running at high speed. To be able to have a strong grip the jockey must have arm or arm muscle strength, and the jockey also needs the strength of the abdominal muscles and leg muscles so that when the jockey on the back of a horse does not feel pain and fear of falling that can reduce concentration in regulating balance when the jockey is is on a racehorse. The balance that jockeys have in driving a horse is very much needed here, from the jockey pushing a horse from the start line to the finish line. Sometimes the horse running is not as stable as the jockey wants, there are some horse running out of the runway, so conditions like this are very important in regulating balance and concentration to make the horse run stable again on the track. Besides physical horse is also very decisive in this horse race, because the one who runs in this race is his horse. Therefore, the horse that will be driven must really be considered from the diet and nutritional intake, body health, and how the training patterns are carried out to improve the skills of the horse to be driven. As stated by (M. Sajoto, 1988:53) The physical condition is one of the intact unity of components that cannot be separated just like that, either its enhancement, its maintenance. This means that in an effort to improve physical conditions, all components must be developed, although here and there a priority system is carried out according to the condition or status of each component and for what needs the state or status needed. 
It's not enough to be a champion in a horse race just to have a good physique. But the jockey must also master a good technique in riding the race horse. The technique basically shows the level of one's coordination ability in doing a movement. because good technical mastery can save energy use, good technical quality can make use of movement more efficient. This means that the better the technique a jockey has, the more efficient the jockey uses the power needed to make a move. Bompa (1999: 60) say that good technique equals high efficiency (good technique $=$ high efficiency). It can be interpreted that there is a positive correlation between the level of technical quality and the level of movement efficiency, or in other words the better the level of athlete's technical skills, the more efficient the power used by athletes in the competition. In addition, the jockey must also know the character of the horse first, such as knowing the physical or psychological condition or condition of the horse that will be driven. Because a jockey is very good even if you don't understand the character of the horse and don't work well with the horse that is being driven then it won't work. Riding a horse is not only a matter of speed or not. However, it must also use the heart so that the rider and horse will become a unity, the inner bond will make the jockey and horse that are driven to understand each other face various conditions that must be passed. If you have mastered the technique in riding a horse, then you must have tactics or strategy when facing an opponent on the track, because the jockey has a strategy or mindset about how to apply the techniques that have been mastered in spurring his horse that is in progress to seek victory. To win the game requires sportsmanship, because sometimes a team has physical and technical superiority but does not apply a good method of competition, it will end in defeat, the method above is called tactics (Djoko Pekik Irianto, 2002: 90).

In addition to the jockey has good physical and technical conditions and tactics, the jockey also needs a strong mentality in the face of the pressure that is experienced. Because it is useless to have physical and technical and good tactics if it is not driven by the mentality of a well-prepared champion, it will be difficult to achieve the achievement goals. Lilik Sudarwati, (2007 :105) revealed in order to improve the quality of athletes we become superior athletes, as one of the factors that has a major influence on the achievements of an athlete, mental factors need special attention. An athlete's mental development can be done early when the athlete is still in the club by a coach. When this mentality is formed, it needs to be improved and maintained at an optimal level. Especially in the field of horse racing many visitors come to watch the race, and encourage the jockeys in various ways they do. Starting from the audience cheering to enter beyond the boundary of the audience into the race track to see up close the interactions of their champions. Things like this are a familiar sight, even though there is already a ban from the security committee implementing committee. However, the audience still entered the track without thinking about the risks they would experience. So the mentality of the jockeys is no less important in dealing with situations that weigh on their appearance. If the jockeys already have a strong mentality, they make a moment like this to motivate themselves in arousing the fighting spirit so as to achieve victory in the race.

Achievements achieved by the jockey are also closely related to achievement motivation, namely the desire to overcome obstacles and challenges faced. Like achievement motivation according Lilik Sudarwati, (2007 :107) Achievement motivation is a strong desire to achieve success or achievement quickly, where success depends on the ability of the athlete itself, with high motivation the jockeys are able to push themselves from feeling bored in the process of training and competition to be of high interest to get the main goal achieve maximum performance. There are several influences that can increase the motivation of jockeys in the horse racing competition according to the results of the study above, revealing the participants of the race will try their best to become champions. Because, being a champion will have many positive effects, including getting a number of prizes given by the horse racing organizing committee, and also many sawers' money given by the jockey's supporters, especially the horse owner will surely give money to the jockey riding his horse. Jockey's income if collected during horse racing activities for a week can earn around 20 to 25 million jockey, so things like this have a big influence on the motivation of the jockeys to become champions.

The custom of the Gayo community is also always to give respect to the jockey and the horse that is being spurred, for example by holding a small party or giving thanks to celebrate the victory achieved by the jockey. And also like a convoy around the area of origin of the jockey so that the jockey who won the horse racing race at that time became popular because it became the talk of the community, and the selling value of the champion horse will soar high that can lift the "Gah" or the spirit of the horse owner and can make the name of the place of origin.

Kemenagan jockeys and horses that are driven can not be separated from the confidence possessed by jockeys while on the racetrack when dealing with other jockeys. In sports self confidence is one of the determining factors for an athlete's success. Problems lacking or losing confidence in one's own abilities will result in athletes appearing below their abilities. Therefore, the athlete does not need to be doubtful about his abilities, as long as he has practiced seriously and has adequate competition experience (Suryanto, 2011). Jockey's confidence cannot just be, but already has preparations from various aspects that support the achievement of victory in the competition. As stated by the informant above, in addition to quality quality driven horses, human resources also determine success in achieving achievement goals in traditional horse racing in the Gayo highlands. Human resources in this activity are jockeys, trainers, and horse owners who provide their horses for the jockeys to ride. Each of these components must have good qualities that can increase the confidence of the jockeys in facing their opponents on the runway. If one of the components is of poor quality, then the goal to achieve achievement cannot be achieved optimally. 
Basically, the traditional Gayo horse race held in Bener Meriah which is the main goal is not only the victory that is obtained on the racetrack, but the most important thing is to fight to achieve victory well. The struggle to achieve victory in a healthy way, does not justify everything for the sake of a victory to achieve the goal of achievement. To achieve the achievement must apply sports values such as sportsmanship, at least every horse race participant obeys the rules in the race that has been set. And always be honest with the final results obtained during the match and also want to recognize the advantages of opponents. And having a caring attitude towards oneself also cares about the opponent, as well as the responsibility in carrying out the given training process.

Although the horse race jockeys in Bener Meriah there is no specific training. However, they continue to earnestly hone their skills autodidactly and are assisted by trainers in the paddy fields and on hilly roads leading to the coffee plantations of farmers in the jockey area. According to Bompa (1994) in Awan Hariono (2006: 1) Exercise is one's effort to improve the improvement of the organism and its function to optimize the performance and appearance of the sport. The aim of the exercise is to get as much achievement as possible, but in the process of implementing the exercise it is not quite easy and simple. The training program provided by the trainer is very important in supporting the quality of training in accordance with their respective branches. It is not only physical training that must be trained to achieve maximum achievement in technique, tactics and mentality is also very important to be trained. Furthermore according to Sukadiyanto (2005: 1), ltraining in principle is a process of change for the better, namely to improve the physical quality of the functional abilities of the body's equipment and the psychic quality of the trainee. In this horse race, not only are jockeys trained. However, the horse also really needs to be trained to get a tough horse that competes later on the runway. As also expressed (Pilliner, 1993) A horse is designed to use its speed to defeat its opponents. A racehorse must be trained to be able to withstand the weight of the rider or jockey and a certain amount of control, but the most determining factor for success is the condition of the horse. In horse racing, not all horses can compete in racehorses. Because most of the horses that take part in the horse race have been spiced and trained for the race to race quickly on the horse race track. To determine a racehorse, there are several requirements and markings on the horse. One of them is a horse that has a vortex of flying and shaped like a deer foot. If the mark is owned, the horse is cared for and trained while being given medicine so that the horse is healthy, strong and ready to compete. There are several ways of training by jockeys or trainers to make their horses reliable when on the racetrack. As some jockeys or trainers put a burden on the horse's legs when carrying out exercises in the paddy field area or on a hilly road through the coffee plantation area, in the hope that when their horses take part in the footsteps race will feel lighter and the horse will run faster. Furthermore, there are also training in horse speed running or horse breathing on the edge of a fresh sea lake. They choose the training ground with the depth of the lake as high as the horse's body, and make the horse spin and run after the horse's favorite mate given by people who can swim or can stimulate the horse's movements so that the horse does the exercise for a long time to get the maximum training results.

Even though a horse is a very strong animal, it can also feel tired when over-training the horse. Therefore you must be able to understand the feelings of a horse by looking at his whole body as he moves and stands. Minutes if the horse's back is raised, this might mean the horse is tired from riding for a long time. In addition to the exercise process, the diet and nutritional intake of the horse also need to be considered as concentrated. Generally the ingredients for making concentrate are rice bran, corn, mung bean flour, soy flour and sometimes added with tofu pulp and rice. This mixture of concentrated feed ingredients is given on normal days. In addition to feeding concentrate, it is also usually given a finely chopped palm tree trunk then dried or can also be given directly after chopping. Unlike the case when a racehorse will be competed in horse racing activities. The concentrate feed given for race preparation is usually the Vital Horse commercial concentrate feed. This concentrate feed is carried out 1 or 2 months before the race is held. At the time of the horse race, usually given to the racehorses concentrated added palm sugar as high energy for the horse. In addition, of course, the jockey must also practice first with the horse that will be his partner, because in this sport, it takes cohesiveness between the jockey and his horse. Horses must be able to obey the jockey, lest the jockey cannot control the horse. Therefore it's good for the jockey and horse to practice first in the original racetrack before the horse race starts to be ready to compete with other jockeys.

\section{CONCLUSION}

The horse race which was originally only held at the edge of Lake Laut to enliven the rice harvest has now become a prestigious big event to achieve the desired achievements. Although the achievements are still at the regional level. However, the contestants prepare themselves carefully. Starting from doing physical training, techniques, tactics, and mental jockey to have to pay attention to the condition of the horse that will be driven. Such as speed, strength and nutritional pattern of the horse that determine the success of the horse to perform his skills on the runway in order to win the championship.

\section{ACKNOWLEDGMENT}

With all humility, all praise and thankfulness of the author make the presence of Allah Almighty for His grace and guidance so that the author can finish writing this paper.The author expresses his gratitude to all those who provided assistance and encouragement in completing this paper. In particular the authors thank you profusely to:

1. Dr.SyamsulGultom, S.KM, M.Kesas Chancellor of Medan State University and all of its staff. 
2. Prof. Dr. BornokSinaga, M.Pdas Director of the Postgraduate of Medan State University and their staff.

3. Dr.Budi Valianto,M.Pd, as Dean of the Faculty of Sports Science. Medan State University and its staff.

4. Dr. Albadi Sinulingga, M.Pd as chairman of the Study Program. Physical Education. Postgraduate of Medan State University and its Staff.

5. Dr.TarsyadNugraha, M.Kes who always helped and directed me in the writing process so that this paper could be finished.

6. Prof.Dr.Agung Sunarno, M.Pd who is not bored giving me encouragement and support so that this paper can be completed.

\section{REFERENCES}

[1] A.M. Sardiman,2001. Interaksi Dan Motivasi Belajar Mengajar. Jakarta: Raja Grafindo Persada.

[2] Awan, Hariono, (2006) "Metode Melatih Fisik Pencak Silat".Yogyakarta: Fakultas Ilmu Keolahragaan Universitas Negeri Yogyakarta.
[3] Bompa, T.O. (1999). Periodization Training For Sport. United States: Human Kinetics.

[4] Djoko Pekik Irianto. (2002). Dasar Kepelatihan. Yogyakarta : FIK UNY

[5] Harsono. 1988. Coaching dan aspek psikologi dalam coaching. Dirjen Dikti: Jakarta.

[6] Irianto,D.P. (2002). Dasar kepelatihan. Yogyakarta: Universitas Negeri Yogyakarta.

[7] Lilik Sudarwati Adisasmito. 2007. Mental Juara Modal Atlet Berprestasi. Jakarta: PT. Raja Grafindo Persada.

[8] M. Sajoto. 1988. Pembinaan Kondisi Fisik Dalam Olahraga.Jakarta: Departemen Pendidikan dan Kebudayaan.

[9] Sukadiyanto. (2005). Pengantar Teori dan Metodologi Melatih Fisik. Yogyakarta.

[10] Suryanto. (2011). Peranan pola hidup sehat terhadap kebugaran jasmani. Artikel Penelitian. Jurusan Pendidikan Kesehatan dan Rekreasi, Fakultas Ilmu Keolahragaan UNY, Yogyakarta.

[11] Piet Rusdi, Pacu Kude ; Permainan Tradisional di Dataran Tinggi Gayo, (Banda Aceh: Balai Pustaka Sejarah dan Nilai Tradisional, 2011).

[12] Pilliner, S. 1993. Getting Horses Fit. Second Editing. Blackwell Science Ltd, London.

[13] Profil Kesehatan Bener Meriah, 2016. 